вчителя, імпровізує у нестандартних ситуаціях, будує навчальний процес, ураховуючи індивідуальні риси особистості студента [3].

Отже, можна стверджувати, що необхідними умовами для вияву творчості у педагогічній діяльності є наявність творчих особистостей, творчого процесу, творчого середовища.

Багато дослідників намагалися створити теорію творчості, але підходи та витлумачення їх істотно відрізнялись. Найпоширеніше визначення творчості зазвичай зводиться до такої формули: творчість - це діяльність, у результаті якої створюються матеріальні й духовні цінності, які мають новизну і суспільну значущість. Ця тенденція характеризувати творчість через новизну і соціальну значущість властива багатьом дослідникам.

Водночас специфікою педагогічної діяльності є розуміння творчості як особливого виду особистісної активності продуктивного характеру. Результати досліджень свідчать про значний вплив біологічних та соціальних умов щодо формування та вияву креативності.

Здатність до творчості в особистості майбутнього вчителя перебуває в тісному взаємозв'язку зі специфікою іiї пізнавальних процесів та особистісних рис. Вияв креативності виражається не стільки у знаннях (правилах, законах), скільки у сприйнятливості до нових проблем, ідей; схильності до руйнування стереотипів задля створення нового.

Ефективність формування творчої особистості майбутніх учителів початкових класів зумовлена виявленням умов й усуненням суперечностей між вимогами, що висуваються до особистості та діяльності майбутнього вчителя початкових класів і наявним рівнем творчої компетентності. Стан досліджуваної проблеми формування творчої компетентності майбутніх учителів початкових класів вимагає подальших наукових пошуків: методика діагностування рівнів сформованості творчої компетентності майбутнього вчителя початкових класів, показники і критерії іiї сформованості, розроблення моделі та технології іiї формування.

\title{
Література
}

1. Бурлачук Л. Ф. Словарь-справочник по психодиагностике / Л. Ф. Бурлачук, С. М. Морозов. [2-е изд.]. - СПб. : Питер, 2004. - 520 с. 2. Морозов А. В. Креативная педагогика и психология: [учеб. пособ.] / А. В. Морозов, Д. В. Чернилевский. - [2-е изд.]. - М. : Академический Проект, 2004. - 560 с. 3. Кузьмина Н. В. Профессионализация личности преподавателя и мастера производственного обучения / Нина Васильевна Кузьмина. - М. : ВШ, 1990. - 118 с. 4. Поташник М. М. Требования к современному уроку: [учеб. пособ.] / Марк Максимович Поташник. - М. : Центр педагогического образования, 2011. - 272 с. 5. Сластенин В. А. Введение в педагогическую аксиологию: [учеб. пособ. для студ.] / В. А. Сластенин, Г. И. Чижакова. - М. : Изд. центр «Академия», 2003. - 192 с. 6. Хомич Л. О. Професійно-педагогічна підготовка вчителя початкових класів / Лідія Олексіївна Хомич. - К. : Магістр-S, 1998. - 201 c.

УДК 378.147: 377. 112.4

Ірина Максименко

\section{ФОРМУВАННЯ ПЕДАГОГІЧНОЇ ТЕХНІКИ В МАЙБУТНІХ ПЕДАГОГІВ ПРОФЕСІЙНОГО НАВЧАННЯ У ПРОЦЕСІ ФАХОВОЇ ПІДГОТОВКИ}

Максименко І. Г. Формування педагогічної техніки в майбутніх педагогів професійного навчання у процесі фахової підготовки.

У статті розкривається сутність і зміст педагогічної техніки та технологія ії̈ формування в майбутніх педагогів професійного навчання, схарактеризовано етапи формування педагогічної техніки під час вивчення дисципліни «Комунікативні процеси в педагогічній діяльності».

Ключові слова: педагогічна техніка, зовнішня техніка, техніка мовлення, внутрішня техніка.

Максименко И. Г. Формирование педагогической техники у будущих учителей профессионального обучения в процессе специальной подготовки.

В статье раскрывается сущность и содержание педагогической техники и технология ее формирования у будущих педагогов профессионального обучения, охарактеризованы этапы формирования педагогической техники при изучении дисциплины «Коммуникативные процессы в педагогической деятельности».

Ключевые слова: педагогическая техника, внешняя техника, техника речи, внутренняя техника. 
Maksimenko I. G. Formation of Educational Technology of the Future Teachers of vocational training in the process of special training.

The article discloses the essence and content of pedagogical technique and the technology of its forming for future teachers of vocational training. The author determines the stages of pedagogical techniques forming during the study of the course «Communication processes in educational activities».

Key words: pedagogical technique, external technique, broadcasting technique, internal technique.

Побудова національної системи освіти в Україні передбачає нові вимоги у процесі фахової підготовки майбутнього педагога професійного навчання до рівня професійної підготовки майбутнього педагога. Розв'язання цієї проблеми вимагає сформованості у вчителя як спеціальних, так і загальнопедагогічних умінь, у системі яких важливе місце посідають уміння педагогічної техніки, які надають змогу учителю перетворювати на апарат педагогічного впливу емоційно виразні засоби (голос, мовлення, міміку, жестикуляцію, емоції), допомагають йому глибше і яскравіше виявити себе, розкрити все професійно значуще в його особистості. Завдяки педагогічній техніці невидима творча діяльність вчителя стає зримою.

Теоретико-методичні аспекти означеної проблеми закладено у працях класиків педагогічної науки А. Макаренка, В. Сухомлинського та наукових дослідженнях педагогів і психологів Ю. Азарова, Г. Балла, І. Зязюна, Н. Кузьміної, В. Лабунської та ін. Вагомим унеском у досліджувану проблему стали наукові праці В. Кан-Калика, Л. Рувинського, М. Тарасевич, у яких розкриваються різні аспекти формування педагогічної техніки переважно у студентів педагогічних вишів. Проблема розвитку педагогічної техніки майбутніх педагогів професійного навчання не знайшла належного висвітлення в науковій літературі. Педагогічна техніка як властивість особистості в переважній більшості ВНЗ цілеспрямовано не формується.

У процесі професійного навчання студент оволодіває певними вміннями педагогічної техніки, водночас самостійно набутий досвід часто буває негативним і виявляється як система шаблонних прийомів, якими користується потім учитель у процесі взаємодії з учнями. Це призводить до значних втрат як в соціальному, так і в особистісному аспектах, оскільки ускладнюються стосунки вчителя 3 учнями, зростає емоційна напруга, незадоволеність педагогічною діяльністю, що негативно впливає як на результативність повсякденної праці, так і на формування професійної майстерності.

Meта статmi - розкрити зміст поетапного формування педагогічної техніки у студентів в процесі вивчення педагогічних дисциплін.

Формування педагогічної техніки потребує визначення іiі сутності та змісту. Частина дослідників розкриває педагогічну техніку в змістовому аспекті як елемент педагогічної технології (І. Дмитрик, І. Зязюн, Н. Тарасевич, О. Шиян, Н. Щуркова). Прихильники іншого напряму відносять до змісту педагогічної техніки ширше коло особистісних утворень, розглядаючи їі крізь призму не тільки емоційно-виразних засобів, але й дидактичних умінь (О. Абдуліна, Г. Баланюк та ін.). Поділяємо позицію А. Макаренка, Л. Рувинського, Ю. Турчанінової, які виокремлюють у педагогічній техніці зовнішню техніку: зовнішні засоби виразності (міміка, жестикуляція, пантоміміка, поза, постава), техніку мовлення (дихання, голос, дикція, інтонація), внутрішню техніку (техніка саморегуляції психічного стану).

На основі теоретичного аналізу ми розглядаємо педагогічну техніку як інтегративну властивість особистості, яка характеризується цілісністю, що виявляється у віддеференційованості від інших властивостей i внутрішньою єдністю іiі складових (емоційно-вольового, змістового, поведінкового) компонентів і реалізується через уміння здійснювати педагогічно доцільний вплив на учасників навчально-виховного процесу емоційно виразними засобами.

Виходячи із визначення педагогічної техніки як властивості особистості і спираючись на положення психолого-педагогічної науки щодо формування якостей особистості на основі єдності емоційно-вольового, раціонального і дієвого компонентів їх розвитку, формування педагогічної техніки здійснювалося в процесі вивчення дисципліни «Комунікативні процеси в педагогічній діяльності» і передбачало такі етапи: пропедевтичний, теоретичний, тренінговий, навчально-моделюючий, корекційно-реалізуючий та контрольний.

Пропедевтичний етап був спрямований на розвиток перцептивної і рефлексивної сторін особистості майбутнього інженера-педагога. Задля цього одним із елементів практичних занять був соціально-психологічний тренінг, за допомогою якого ми намагалися допомогти кожному 
студенту адекватно й повно сприймати себе та інших, відображати групові процеси через розвиток умінь рефлексування $\mathrm{i}$ коректування власної поведінки, своїх соціальноперцептивних здібностей, діагностування процесу міжособистісної взаємодії.

Завданнями теоретичного етапу було оволодіння теоретичними знаннями, усвідомлення значимості педагогічної техніки у становленні професійної майстерності майбутнього вчителя. Крім того, розглядуваний етап передбачав діагностування i набуття певного досвіду використання педагогічної техніки в процесі взаємодії, шляхом залучення студентів до активної діяльності, яка вимагала виконання певних завдань відповідно до теми заняття. Наприклад: визначити емоційну інтонацію, з якою було виголошено привітання викладача (Тема: «Техніка мовлення»), або визначити психічний стан викладача на різних етапах читання лекції (Тема: «Техніка саморегуляції педагога»).

На тренінговому етапі відпрацьовувалася система окремих навичок, які характеризують певний елемент педагогічної техніки. Задля цього використовувалися розроблені нами чи модифіковані серії методик, які надавали змогу кожному усвідомити особливості власної педагогічної техніки, іiі позитивні сторони і недоліки, шляхи їх усунення, оволодівати способами самовдосконалення. Критеріями відбору вправ, педагогічних задач, ситуацій були аспектність проблеми, функціональна спрямованість та складність елементу педагогічної техніки. Серії завдань були спрямовані на розвиток навичок і умінь саморегуляції, техніки мовлення, техніки невербальної поведінки.

На окресленому етапі на основі запропонованих зразків правильної поведінки студенти відтворювали іiї в різних вправах і ситуаціях і надалі шляхом аналізу з'ясовувалися причини типових помилок, окреслювалися шляхи їх усунення, алгоритмізувався цей процес. На подальших етапах систему вправ для відпрацювання відповідних навичок будували за принципом ускладнення, розкриваючи технологію процесу їх формування.

Розвиток умінь педагогічної техніки на навчально-моделюючому етапі здійснювався шляхом залучення студентів до активної діяльності в системі педагогічного імітаційного та імпровізаційного ігрового моделювання задля інтеріоризації навичок, відповідних кожному елементу педагогічної техніки, формування умінь переносити набуті навички в нові ситуації в умовах групової дискусії й ситуаційно-рольової гри. У груповій дискусії кожен учасник тренінгу мав змогу висловити свою думку з проблеми, що сприяло формуванню мовленнєвих умінь, умінь триматися перед аудиторією й адекватно до змісту мовлення і ситуації використовувати зовнішні засоби виразності.

Під час аналізу діяльності студентів особлива увага зосереджувалася на засобах, які ними використовувалися для встановлення контакту, спонукання партнера до взаємодії: а) мовленнєві, б) паралінгвістичні, в) уміння управляти собою й коректувати емоційний стан співрозмовника, г) адекватність невербальної поведінки і мовлення особливостям ситуації та партнерів по спілкуванню.

Використання рольової гри як методу, який створює можливість відтворити в навчальних умовах ситуації реального навчально-виховного процесу i забезпечити більш природну мовленнєву діяльність і невербальну поведінку, підвищувало мотивацію оволодіння педагогічною технікою, створювало можливості для ефективного розвитку ії комплексних умінь. Ситуаційнорольові ігри в нашому дослідженні виконували дві функції: 1) діагностування - у процесі гри аналізувався рівень сформованості педагогічної техніки; 2) розвиток умінь педагогічної техніки. Рольова гра створювала можливості для накопичення досвіду використання умінь педагогічної техніки в процесі взаємодії, що сприяє, з одного боку, закріпленню сформованих навичок, а 3 іншого, - формуванню умінь імпровізації. Непередбачені дії однієї дійової особи вимагали корекції дій з боку іншої, що сприяло розвитку умінь обирати оптимальні вербальні та невербальні засоби, змінювати внутрішній стан і приводити його у відповідність до нових умов.

У процесі аналізу «захист» свого варіанту використання прийомів педагогічної техніки сприяв установленню зв'язків між теоретичними знаннями та їх практичним застосуванням, що, відповідно, сприяло формуванню умінь гнучко підходити до вибору засобів педагогічної техніки, створювало можливість відійти від стереотипу в мовленнєвих діях і невербальній поведінці.

Корекційно-реалізуючий етап був спрямований на самовдосконалення набутих умінь педагогічної техніки в реальних умовах навчально-виховного процесу в період педагогічної практики. Аналіз проведених студентами занять показав, що одні 3 них здійснювали самодіагностування i розпочинали корекцію необхідних форм поведінки. Для інших - 
самодіагностування виявилося більш складним процесом: нерідко частині студентів треба було докладати чимало зусиль, щоб зрозуміти, що вони представлені іншим зовнішніми засобами виразності й мовленням не так, як бачать самі себе. 3 урахуванням особистісного чинника виявлялися причини утруднень, розроблялася система вправ, яка ефективно впливала на розвиток тієї чи тієї групи умінь.

Постійний самоаналіз, у процесі якого студент не порівнював себе з іншими, а оцінював власні досягнення, контроль, у результаті якого вносилися необхідні корективи в його діяльність в аспекті використання педагогічної техніки, блокували непродуктивні форми поведінки і стимулювали досягнення кожного.

Контрольний етап засвідчив суттєві зміни в розвитку педагогічної техніки, що виявилося в більш глибоких усвідомлених знаннях, вільному оперуванні понятійним апаратом, здатністю до творчого їх використання в різноманітних ситуаціях взаємодії. Кількість студентів, які виявили достатній рівень знань, - 78,1\% (на діагностувальому етапі їх кількість складала 25,1\%).

Оцінку студентами значимості педагогічної техніки у професійній діяльності неможливо віднести до статистичного показника. Вона значною мірою характеризується динамічністю і змінюється в досить широкому діапазоні - від високої до упевненості в непотрібності педагогічної техніки. Проведена робота внесла певні зміни: виражену готовність до оволодіння педагогічною технікою виявили $44,4 \%$ студентів, частково виражену $-55,7 \%$ (на констатуваьному етапі ці групи складали відповідно 18,6\% і 25,6\%).

Відбулися зміни в рівнях процесуального компонента педагогічної техніки. Порівняльний аналіз показав зростання з 6,9\% до 18,6\% групи студентів із достатнім рівнем сформованості педагогічної техніки. Чисельність групи з низьким рівнем зменшилася на 39,6\%.

Окрім прямих, були виявлені й деякі опосередковані, але дуже важливі результати. До них відносяться передовсім підвищення задоволеності студентів професійною діяльністю. Зростання рівня сформованості педагогічної техніки знизила установку на неї як на другорядний елемент педагогічної майстерності.

Проведене дослідження довело:

- не існує однозначного зв'язку між змістовим і процесуальним аспектами педагогічної техніки. Результати дослідження свідчать, що хоча змістовий аспект виражається в процесуальному, а отже, детермінує його, процесуальний рівень педагогічної техніки має деяку відносну самостійність. І тому форма поведінки педагога не завжди повністю відповідає змісту знань та ставленню до педагогічної техніки, а в окремих випадках і зовсім не відповідає їм;

- уміння педагогічної техніки мають динамічні особливості, співвідносяться між собою на різних рівнях. Визначена рівнева класифікація є важливим засобом у процесі розвитку педагогічної техніки, який дозволяє коригувати перехід студентів у вищу рівневу групу, що робить процес розвитку її умінь керованим, педагогічно регульованим і конкретним відносно кожного студента.

Отже, організація цілеспрямованого навчання умінням педагогічної техніки, організація форм і методів, спрямованих на розвиток емоційно-вольового, змістового й діяльнісного ії компонентів як цілісності, формування рефлексивної позиції студента, яка грунтується на самосвідомості й самовизначенні відносно власної педагогічної техніки, використання особистісно-діяльнісного підходу дозволяють успішно розв'язувати завдання формування в майбутніх педагогів професійного навчання педагогічної техніки.

\section{Література}

1. Кузьмина Н. В. Актуальные проблемы профессионально-педагогической подготовки учителя / Н. В. Кузьмина, В. И. Гинецианский // Советская педагогика. - 1982. - № 6. - С. 60-68. 2. Кусый Ю. А. Приемы формирования педагогической техники у будущих педагогов [голосовой тренинг] / Ю.А.Кусый. - Днепропетровск: Изд-во Днепропетровского ун-та, 1989. - 72 с. 3. Макаренко А. С. О моем опыте. Педагогические соч.: в 8 т. / М. Д. Виноградова, А. А. Фролов. М. : Педагогика, 1984. - Т. 4. - 1984. - 400 с. 4. Омельченко С. Д. Формирование педагогической техники как компонента педагогической культуры учителя: дис. ... канд. пед. наук: 13.00.01/ С. Д. Омельченко. - Харьков, 1995. - 249 с. 5. Сластенин В. А. Формирование личности учителя советской школы в процессе профессиональной подготовки / В. А. Сластенин. - М. : Просвещение, 1976. - 160 с. 6. Сухомлинский В. А. О поступках / В. А. Сухомлинский // Советская педагогика. 1970. - № 11. - С. 31-37. 7. Учителю о педагогической технике / под ред. Л. И. Рувинского. - М. : Педагогика, 1987. $-160 \mathrm{c}$. 